\title{
Effects of long-term fertilization and mulch on soil fertility in contour hedgerow systems: A case study on steeplands from the Three Gorges Area, China
}

\author{
Zhi-Hua Shi · Li-Ding Chen · Chong-Fa Cai • \\ Zhao-Xia Li · Guo-Hua Liu
}

Received: 31 March 2008/Accepted: 13 October 2008/Published online: 29 October 2008

(C) Springer Science+Business Media B.V. 2008

\begin{abstract}
The use of contour hedgerows is widely advocated to sustain crop production and reduce soil loss on steeplands in the Three Gorges Area of China. However, little is known about the effects of soil management on soil fertility within these systems, or about the spatial gradients in soil nutrients that may develop in terraces formed behind the vegetative barriers. Therefore, we carried out a study on the effects of various long-term soil management practices on soil fertility and spatial variation of fertility between hedgerows. At a site in the Three Gorges Area, China, we applied five treatments to a contour hedgerow system: control (no fertilizer and manure); chemical fertilizer $(\mathrm{CF})$; chemical fertilizer and mulch $(\mathrm{CF}+\mathrm{MU})$; pig manure $(\mathrm{PM})$; and mulch, pig manure, and chemical fertilizer $(\mathrm{CF}+\mathrm{PM}+\mathrm{MU})$. Soil samples were collected from the topsoil horizon $(0-20 \mathrm{~cm})$ of the selected five treatments in 2006 after 11 crop cycles, and physical and chemical properties
\end{abstract}

Z.-H. Shi · L.-D. Chen ( $\) \cdot$ G.-H. Liu

State Key Laboratory of Urban and Regional Ecology, Research Center for Eco-environmental Sciences, Chinese Academy of Sciences, PO Box 2871, Beijing 100085, Peoples Republic of China

e-mail: liding@rcees.ac.cn

Z.-H. Shi · C.-F. Cai · Z.-X. Li

Key Lab of Subtropical Agriculture and Environment Ministry of Agriculture, Huazhong Agricultural University, Wuhan 430070, Peoples Republic of China were analyzed. The results showed that chemical fertilizer clearly improves nutrient status of the topsoil, while pig manure also increased the amount of soil organic matter. This increase in organic matter was associated with an increase in soil aggregate stability, a reduction in bulk density, and reduced penetration resistance of the soil. Mulch with pig manure and chemical fertilizer was the best management practice for improving soil quality and crop yields in the Three Gorges Area. Further, mulch and pig manure addition also decreased the magnitude of the spatial variation, but did not offset the soil fertility gradients because tillage resulted in significant movement of soil. More favorable soil properties were found at the lower positions within each alley, regardless of the management practice applied.

Keywords Soil physical properties .

Soil chemical properties - Fertility gradient .

Crop yield $\cdot$ Contour hedgerow

\section{Introduction}

Approximately 800 million people worldwide depend directly on steeplands for their sustenance (Drees et al. 2003). Of the total area of $62,640 \mathrm{~km}^{2}$ in the Three Gorges Area, $52.1 \%$ has gradients of between $7^{\circ}$ and $25^{\circ}$, and $37.5 \%$ has gradients of more than $25^{\circ}$ (Zhou 2001). After construction of the Three Gorges 
Dam, many farmers resettled in the surrounding mountain areas. The steeplands with slope gradients of greater than $20 \%$, which were largely forested, have been widely cleared for cultivation. Thus, many of the steeplands are subject to catastrophic mass movement and slumping, leading to increased land degradation, accelerated erosion and nutrient loss, and loss of sustainable production. It was reported that annual soil loss in the Three Gorges Area is approximately 157 million tons, $46.2 \%$ of which comes from cultivated steeplands (Du et al. 1994). Most soils are less than $50 \mathrm{~cm}$ thick, and A- and B-horizons or even C-horizons are absent (Du et al. 1994). Steeplands management is a key factor determining ecological sustainability in this area. If this problem is not adequately addressed, not only will the well-being of the local people suffer, but also the functionality of the Three Gorges Dam and Reservoir will also be undermined due to siltation and eutrophication.

The contour hedgerow system is a simultaneous agroforestry system in which rows of trees or shrubs are planted along contours at 3-6 $\mathrm{m}$ intervals within the slope field. Crops are produced in the alley-like spaces between the hedgerows (Sun et al. 2008). Hedgerows can reduce the generation of runoff, and can intercept eroded sediments from the upper slopes so that soil fertility can be conserved (Lal 1989a). Xu et al. (2000) reported that runoff and soil loss from contour hedgerow systems were only $24.8 \%$ and $16.9 \%$, respectively, of that from agricultural steeplands under traditional management in the Three Gorges Area. Furthermore, hedgerows can be clipped two to three times a year, and clippings can be used as green manure so that less external nutrient input is required (Isaac et al. 2003). In contour hedgerows, terraces form naturally over time as soil moves from the upper part of the alley and accumulate on the lower side of the alley next to the hedge. Shen (1998) and Zhao et al. (2004) reported that bio-terraces can form on $15-25^{\circ}$ slopes after $4-7$ years by planting hedgerows. The cost of bio-terraces is only $3-17 \%$ of that of engineered terraces, and they are also much more stable (Sun et al. 2008). However, due to the limited soil depth in the Three Gorges Area, this type of terrace is often associated with high spatial variability in soil fertility and crop responses. This is attributed to the movement of topsoil from the upper part down to the buffer-strips of the terraces, which exposes infertile subsoil near the upper part of the terrace (Dercon et al. 2003).

Although contour hedgerows were introduced to the Three Gorges Area by the local government as a soil conservation measure in the late 1980s, little is known about the effects of soil management on the soil fertility of these systems, or the spatial gradients in soil nutrients that may develop in the terraces as they evolve behind the vegetative barriers. Long-term experiments provide the best possible means for studying changes in soil fertility and thus, for obtaining valuable information required for formulating future strategies for maintaining soil health. Against this background, this study was undertaken to quantify the changes in soil fertility and its spatial variation in contour hedgerow systems in the Three Gorges Area. These hedgerows have formed under the influence of long-term soil management practices that are commonly used in this area, including the use of chemical fertilizers, organic manure, and mulch.

\section{Materials and methods}

Description of the study area

The study was carried out in Wangjiaqiao $\left(31^{\circ} 12^{\prime} \mathrm{N}\right.$, $\left.110^{\circ} 42^{\prime} \mathrm{E}\right)$, Zigui County, Hubei Province, which is a typical village located approximately $50 \mathrm{~km}$ northwest of the Three Gorges Dam (Fig. 1). Wangjiaqiao was chosen as study site because it was representative of villages in the Three Gorges Area, both geographically and socio-economically. Natural resources, land-use patterns, and population densities are typical of the surrounding region. Its annual average temperature is $18^{\circ} \mathrm{C}$, with an average summer high of $28^{\circ} \mathrm{C}$ in July and an average winter low of $8^{\circ} \mathrm{C}$ in January. Annual precipitation averages $1,016 \mathrm{~mm}$, of which $70 \%$ occurs between May and September. The major agricultural crops are rice (Oryza sativa L.), wheat (Triticum aestivum L.), maize (Zea mays L.), rape (Brassica napus L.), and soybean (Glycine max L.). The local soil type is purple soil (Regosols in FAO Taxonomy, or Entisols in USDA Taxonomy) developed from purple sandy shale. Purple soil is the most common soil type in the Three Gorges Area, and covers approximately $78.7 \%$ of the land area (Du et al. 1994; He 2003). 
Fig. 1 Location of the study area and photograph of study runoff plot
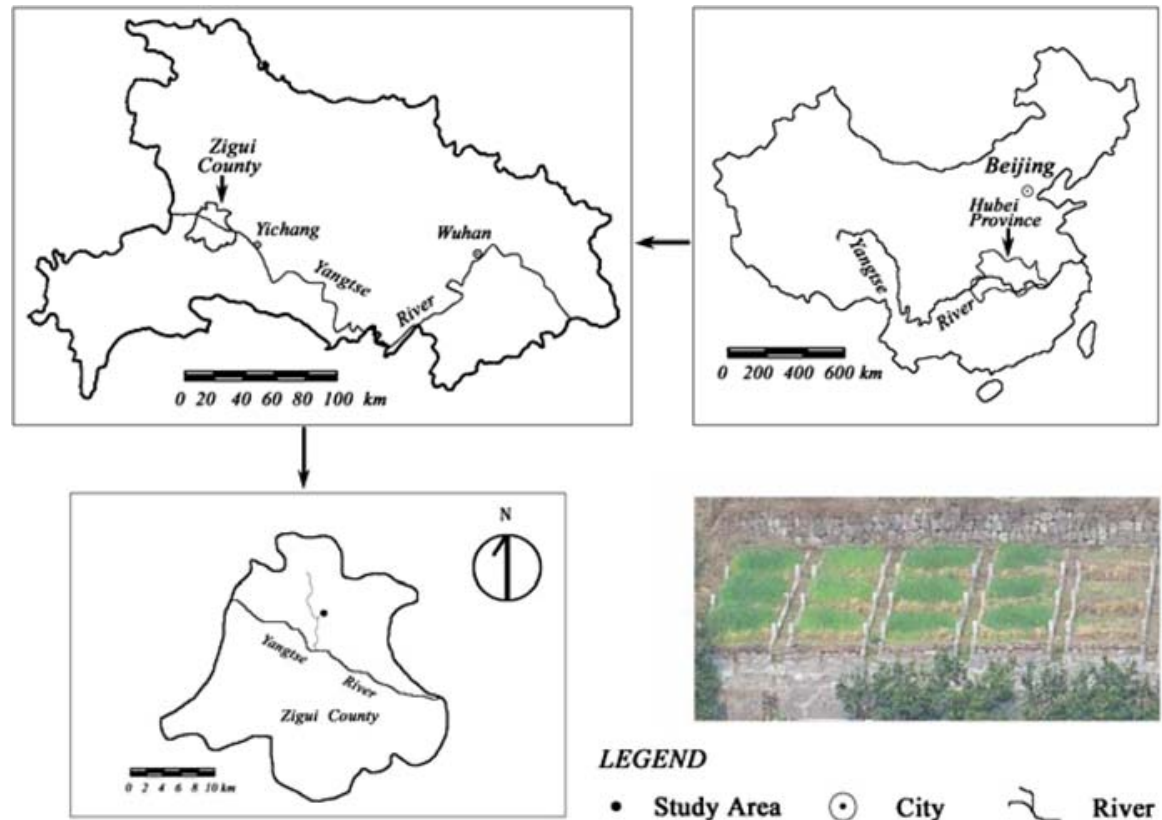

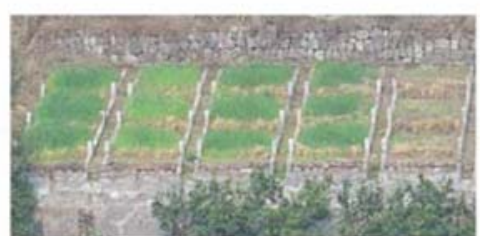

LEGEND

- Study Area $\odot$ City $ح$ River
Experimental design

In 1996, five runoff plots with $0.4 \mathrm{~m}$ spacing were laid out within a $240 \mathrm{~m}^{2}$ fenced experimental site (Fig. 1). The site is abandoned farmland with a $23-26^{\circ}$ slope. Soil depth was less than $20 \mathrm{~cm}$ at the start of experiments. The runoff plots were delineated by $10-\mathrm{cm}$ cement ridges projecting aboveground to isolate plot runoff and sediment. A discharge ditch was created at the top of each plot to divert runoff and sediments from the upper slope. At the base of each plot, a volumetrically calibrated tank was positioned to collect runoff and sediment, and was connected with a notch. After the site was prepared, all plots were covered with $20 \mathrm{~cm}$ purple soil at a bulk density of $1.3 \mathrm{Mg} \mathrm{m}^{-3}$, which was taken at a depth of 0-20 cm from adjacent steeplands and thoroughly mixed before covering the five plots. Table 1 summarizes selected soil properties. Because of financial and resource constraints, plots were not replicated in this study. To minimize problems associated with non-replication, these plots were constructed and managed identically in terms of layout, dimensions, material and location, etc. (Hurlbert 1984).

In all plots, three rows of Vetiver (Vetiveria zizanioides L.) were planted along contours at $4 \mathrm{~m}$ intervals. Within each plot, three $2 \times 4 \mathrm{~m}^{2}$ microplots were allocated for growing crops. Vetiver is a
Table 1 Selected soil properties before experiment (sampling on March 1996)

\begin{tabular}{lc}
\hline Soil properties & Values \\
\hline Soil organic carbon $\left(\mathrm{g} \mathrm{kg}^{-1}\right)$ & 10.6 \\
$\mathrm{pH}$ in $\mathrm{H}_{2} \mathrm{O}(1: 1$ suspension) & 8.06 \\
Total N $\left(\mathrm{g} \mathrm{kg}^{-1}\right)$ & 0.81 \\
Total P $\left(\mathrm{g} \mathrm{kg}^{-1}\right)$ & 0.64 \\
Total K $\left(\mathrm{g} \mathrm{kg}^{-1}\right)$ & 23.8 \\
Available N $\left(\mathrm{mg} \mathrm{kg}^{-1}\right)$ & 49.9 \\
Available P $\left(\mathrm{mg} \mathrm{kg}^{-1}\right)$ & 3.97 \\
Available K $\left(\mathrm{mg} \mathrm{kg}^{-1}\right)$ & 123.5 \\
Bulk density $\left(\mathrm{Mg} \mathrm{m}^{-3}\right)$ & 1.31 \\
Sand $\left(\mathrm{g} \mathrm{kg}^{-1}\right)$ & 468 \\
Silt $\left(\mathrm{g} \mathrm{kg}^{-1}\right)$ & 413 \\
Clay $\left(\mathrm{g} \mathrm{kg}^{-1}\right)$ & 119 \\
$>0.25 \mathrm{~mm} \mathrm{water-stable} \mathrm{aggregates}(\%)$ & 37.7 \\
\hline
\end{tabular}

fast growing herbaceous plant with deep and farranging roots (up to $2-3 \mathrm{~m}$ ). It is commonly used to control soil erosion in cultivated fields in tropical and subtropical regions (Greenfield 1989). Wheat (Triticum aestivum L.) was grown between October and May, and soybean (Glycine max L.) between June and September, as is the normal practice for crop production in this area. Soil management practices, including chemical fertilizers, pig manure, and mulch, were used in this study. Five experimental 
treatments are shown in Table 2. $\mathrm{N}$ was supplied as urea and $\mathrm{P}$ as single superphosphate. Pig manure was sourced from a local farmer. Fertilizer was applied only to wheat each year, following the normal farming practice in the area. Pig manure and single superphosphate were applied as basal fertilizer before plowing in mid October. Urea was applied in three equal applications, the first applied as basal fertilizer before sowing, the second as side-dressing $30 \mathrm{~d}$ after planting, and the third as another side dressing $30 \mathrm{~d}$ after the first side-dressing. Wheat straw was applied as mulch at $2 \mathrm{Mg} \mathrm{ha}^{-1}$ twice each year in May and November. These two mulch applications were approximately the same time as crop sowing in the first and second growing seasons. Pests and diseases were controlled with pesticide, while weeding was carried out by hand. After crop harvest, all aboveground crop residues were removed from each plot.

Soil sampling and analysis

Soil was sampled in bands between two contour hedgerows, which were located every $1.3 \mathrm{~m}$ beginning at the lower contour hedgerow. One sample was taken from each band, and three bands were sampled within each micro-plot. The three samples represented lower, middle, and upper slope positions of the micro-plot. Samples were taken at a depth of 0-20 cm, and a total of 45 samples were taken from five plots in October 2006. At each sampling position, soil samples were collected from 5 to 7 points and mixed to get a composite sample. Stones, roots, and large organic residues were carefully removed from the field-moist soil samples. Approximately one quarter, or $500 \mathrm{~g}$ of the soil was sub-sampled from the mixed composite sample, and approximately $200 \mathrm{~g}$ of this soil was reserved for aggregate analysis.

Selected soil properties were determined using routine methods (ISSAS 1978; Liu 1996). Soil bulk density (BD) was determined by oven-drying and weighing cores of known volume taken from the undisturbed field soils. Soil structural stability was estimated by the wet sieving method and expressed as percentage of water stable aggregates (\% WSA). Soil texture was determined by the hydrometer method. Penetration resistance (PR) was measured for the 0-20 cm depth layer with a blunt-tip pocket penetrometer by digging small pits during sampling. Soil $\mathrm{pH}$ was measured using a glass electrode with a soil/ water ratio of $1: 1$. Soil organic matter (SOM) was determined using an oil bath- $\mathrm{K}_{2} \mathrm{CrO}_{7}$ titration method, total nitrogen (TN) by the Kjeldahl method, and available nitrogen (AN) by the alkaline potassium permanganate distillation method. Total phosphorus (TP) and total potassium (TK) were determined after digesting soil with $\mathrm{H}_{2} \mathrm{SO}_{4}-\mathrm{HClO}_{4}$. Available phosphorus (AP) in soil was determined by extracting samples with $0.5 \mathrm{~mol} \mathrm{l}^{-1} \mathrm{NaHCO}_{3}$, then determining $\mathrm{P}$ colorimetrically using the molybdate blue method. Available potassium (AK) was determined using $1 \mathrm{~mol} \mathrm{l}^{-1}$ ammonium acetate extraction followed by emission spectrometry.

Biomass and crop yield measurements

All above-ground crop biomass was harvested manually from all micro-plots at the end of each growing season. Grain and straw parts were separated and weighed. Contour hedgerows were pruned three times each year, in May, August, and October. The top

Table 2 Details of treatments. MU, PM, and CF are wheat straw mulch, pig manure, and chemical fertilizer, respectively

\begin{tabular}{lllll}
\hline Treatments & \multicolumn{2}{l}{ Average annual fertilizer application $\left(\mathrm{kg} \mathrm{ha}^{-1}\right)$} & \multicolumn{2}{c}{ Mulch $\left(\mathrm{kg} \mathrm{ha}^{-1}\right)$} \\
\cline { 2 - 4 } & $\mathrm{N}$ & $\mathrm{P}$ & Pig manure $^{\mathrm{a}}$ & NA \\
\hline Control & $\mathrm{NA}^{\mathrm{b}}$ & $\mathrm{NA}$ & $\mathrm{NA}$ & $\mathrm{NA}$ \\
$\mathrm{CF}$ & 150 & 45 & $\mathrm{NA}$ & 4,000 \\
$\mathrm{CF}+\mathrm{MU}$ & 150 & 45 & $\mathrm{NA}$ & $\mathrm{NA}$ \\
$\mathrm{PM}$ & $\mathrm{NA}$ & $\mathrm{NA}$ & $20,000-25,000$ & 4,000 \\
$\mathrm{CF}+\mathrm{PM}+\mathrm{MU}$ & 75 & 22.5 & $10,000-12,500$ & \\
\hline
\end{tabular}

\footnotetext{
${ }^{\mathrm{a}} \mathrm{N}, \mathrm{P}$, and $\mathrm{K}$ concentrations in pig manure were $6.5-7.6,1.8-2.4$, and $3.5-4.6 \mathrm{~g} \mathrm{~kg}^{-1}$, respectively

b Not applied
} 
$50 \mathrm{~cm}$ of the hedge was cut and weighed, and then clippings were placed at the base of hedge as green manure. Three plant samples were collected after the experiment to determine the ratio of clipped to residual parts. Dry matter content of grain, straw, and clippings was determined from $200 \mathrm{~g}$ oven-dried samples. Grain yield for the whole plot was calculated based on total land area.

\section{Calculation of soil deterioration indices}

The soil deterioration index (Adejuwon and Ekanade 1988) was calculated on the assumption that each individual soil property under the different treatments had once been the same as the reference soil (at the start of experiments). The difference between mean values of individual soil properties under the five treatments compared with base values of reference soil properties was calculated, and was expressed as a percentage of the base value for each individual property. These percent values were then averaged across all soil properties to calculate the soil deterioration index.

\section{Statistical analysis}

All data were analyzed using SPSS software. Oneway analysis of variance (ANOVA) was carried out for each soil property among the different treatments or position of micro-plots to determine significance among differences $(P<0.05)$. When necessary, data were $\log$-transformed prior to statistical analysis to achieve normal distribution of data. Mean values were compared using least significant difference (LSD).

\section{Results and discussion}

\section{Soil properties}

Soil responses to different management practices are shown in Table 3. Among the 14 soil properties tested, 9 properties were significantly affected by mulch, chemical fertilizers, and pig manure. These properties included bulk density (BD), penetration resistance (PR), percentage of $>0.25 \mathrm{~mm}$ water stable aggregates (\% WSA), soil organic matter (SOM), total $\mathrm{N}(\mathrm{TN})$, total $\mathrm{P}(\mathrm{TP})$, available $\mathrm{N}(\mathrm{AN})$, available $\mathrm{P}$ (AP), and available $\mathrm{K}(\mathrm{AK})$. The remaining five properties $(\mathrm{pH}$, clay, sand, silt, and TK) were excluded because they failed to meet the screening criteria. A similar screening approach was used by Sharma et al. (2005).

\section{Soil organic matter}

Soil organic matter $(\mathrm{SOM})$ was significantly $(P<$ $0.05)$ affected by long-term application of chemical fertilizer, pig manure, and/or mulch (Table 3). Both $\mathrm{PM}$ and $\mathrm{CF}+\mathrm{PM}+\mathrm{MU}$ treatments resulted in significantly higher SOM (17.12 and $16.47 \mathrm{~kg} \mathrm{~kg}^{-1}$, respectively) than all other treatments. Further, the SOM content in control and CF plots was the same as the initial SOM level $\left(10.6 \mathrm{~kg} \mathrm{~kg}^{-1}\right)$ (Table 1), while the SOM content in $\mathrm{CF}+\mathrm{MU}, \mathrm{PM}$, and $\mathrm{CF}+$ $\mathrm{PM}+\mathrm{MU}$ treatments reached new equilibria that were $26.3,61.5$, and $55.4 \%$ higher, respectively, than the initial SOM level. Generally, intensive cropping causes a decline in SOM over time (Lal 1989b). In the present study, however, the SOM status in unfertilized plots showed no decline even after 11 years of cropping, apparently because of the low SOM equilibrium $\left(10.6 \mathrm{~kg} \mathrm{~kg}^{-1}\right)$ in the experimental soil at the initiation of experiments in 1996. The hedgerow clippings may have helped to maintain the SOM level in control and $\mathrm{CF}$ treatments. In the $\mathrm{PM}$ and $\mathrm{CF}+\mathrm{PM}+\mathrm{MU}$ treatments, direct addition of organic matter from the farmyard manure increased the organic matter content (Benbi et al. 1998).

\section{Soil physical properties}

The percentage of $>0.25 \mathrm{~mm}$ water stable aggregates (\% WSA) in CF + PM + MU and PM treatments was about twice that of the control (Table 3). The \% WSA was significantly higher when mulch was applied instead of chemical fertilizer (46.7 versus 36.6\%, $P<0.05)$. Formation of water-stable aggregates was greater after addition of pig manure than after addition of chemical fertilizers (49.9 versus $36.6 \%, P<0.01$ ). Therefore, enhanced soil aggregate stability was consistent with greater input of organic matter. The organic matter stabilizes the aggregates by forming and strengthening bonds among clay domains and between quartz particles and clay domains (Tisdall and Oades 1982; Albiach et al. 2001). Moreover, mulch on the soil surface can decrease erosion, reduce evaporation, protect against raindrop impact, and increase 
Table 3 Effects of soil management on selected soil properties

\begin{tabular}{|c|c|c|c|c|c|c|}
\hline Soil properties & Control & $\mathrm{CF}$ & $\mathrm{CF}+\mathrm{MU}$ & PM & $\mathrm{CF}+\mathrm{PM}+\mathrm{MU}$ & $\begin{array}{l}\text { ANOVA } \\
P \text { value }\end{array}$ \\
\hline Bulk density $\left(\mathrm{Mg} \mathrm{m}^{-3}\right)$ & $1.34 \mathrm{a}$ & $1.30 \mathrm{ab}$ & $1.26 \mathrm{bc}$ & $1.24 \mathrm{c}$ & $1.22 \mathrm{c}$ & 0.04 \\
\hline $\begin{array}{l}\text { Penetration resistance } \\
\qquad\left(\mathrm{kg} \mathrm{cm}^{-2}\right)\end{array}$ & $1.81 \mathrm{a}$ & $1.56 \mathrm{~b}$ & $1.17 \mathrm{~cd}$ & $1.38 b c$ & $1.07 \mathrm{~d}$ & 0.002 \\
\hline$>0.25 \mathrm{~mm}$ WSA $(\%)$ & $25.2 \mathrm{c}$ & $37.7 b$ & $47.7 \mathrm{a}$ & $49.9 \mathrm{a}$ & $51.4 \mathrm{a}$ & 0.003 \\
\hline Soil organic matter $\left(\mathrm{g} \mathrm{kg}^{-1}\right)$ & $9.65 \mathrm{c}$ & $11.67 \mathrm{~b}$ & $13.39 \mathrm{~b}$ & $17.12 \mathrm{a}$ & $16.47 \mathrm{a}$ & $<0.001$ \\
\hline Total $\mathrm{N}\left(\mathrm{g} \mathrm{kg}^{-1}\right)$ & $0.64 d$ & $0.84 \mathrm{c}$ & $0.92 b c$ & $0.95 b$ & $1.12 \mathrm{a}$ & $<0.001$ \\
\hline Total $\mathrm{P}\left(\mathrm{g} \mathrm{kg}^{-1}\right)$ & $0.55 \mathrm{c}$ & $0.76 b$ & $0.85 \mathrm{ab}$ & $0.82 b$ & $0.92 \mathrm{a}$ & 0.002 \\
\hline Available $\mathrm{N}\left(\mathrm{mg} \mathrm{kg}^{-1}\right)$ & $44.7 d$ & $54.4 \mathrm{c}$ & $62.6 b$ & $58.7 \mathrm{bc}$ & $78.3 \mathrm{a}$ & $<0.001$ \\
\hline Available $\mathrm{P}\left(\mathrm{mg} \mathrm{kg}^{-1}\right)$ & $3.28 \mathrm{c}$ & $4.78 b$ & $6.34 b$ & $9.58 \mathrm{a}$ & $9.26 \mathrm{a}$ & 0.005 \\
\hline Available $\mathrm{K}\left(\mathrm{mg} \mathrm{kg}^{-1}\right)$ & $115.2 \mathrm{c}$ & $131.7 \mathrm{~b}$ & $138.9 b$ & $143.0 \mathrm{ab}$ & $155.5 \mathrm{a}$ & 0.03 \\
\hline
\end{tabular}

MU, PM, and CF are wheat straw mulch, pig manure, and chemical fertilizer, respectively

Same letter(s) on same rows indicates non-significant difference $(P<0.05, \mathrm{LSD})$

aggregate stability (Layton et al. 1993). The ability of soil organic matter to promote the formation of water stable aggregates has a profound effect on soil physical properties (Haynes and Naidu 1998). The bulk density (BD) in the control was significantly higher than in $\mathrm{CF}+\mathrm{MU}, \mathrm{PM}$, and $\mathrm{CF}+\mathrm{PM}+\mathrm{MU}$ treatments (by $0.08,0.10$, and $0.12 \mathrm{Mg} \mathrm{m}^{-3}$, respectively; Table 3). Bulk density did not differ significantly among $\mathrm{CF}+\mathrm{MU}, \mathrm{PM}$, and $\mathrm{CF}+\mathrm{PM}+\mathrm{MU}$ treatments. The reduction in $\mathrm{BD}$ could be attributed to higher organic matter content of the soil, better aggregation and a consequent increase in the volume of micropores, and increased root growth in the manure-treated plots (Schjonning et al. 1994). Alongside the change in soil bulk density, the penetration resistance (PR) also decreased from $1.81 \mathrm{~kg} \mathrm{~cm}^{-2}$ in the control to $1.07 \mathrm{~kg} \mathrm{~cm}^{-2}$ in the $\mathrm{CF}+\mathrm{PM}+\mathrm{MU}$ treatment. Treated mulch had the lowest penetration resistance, and the PR of $\mathrm{CF}+\mathrm{MU}$ and $\mathrm{CF}+\mathrm{PM}+\mathrm{MU}$ was 1.17 and $1.07 \mathrm{~kg} \mathrm{~cm}^{-2}$, respectively. This may be partly attributed to the high soil moisture in the soil profile resulting from the reduced surface runoff and soil evaporation after mulch application. Soil moisture is the dominant factor influencing the force required to push a penetrometer into the soil, with PR increasing as the moisture content decreases (Shaw et al. 1942).

\section{Soil chemical properties}

Compared with the control, the other treatments showed significantly improved nutrient status in the topsoil, with the highest values in the $\mathrm{CF}+\mathrm{PM}+$ MU plot (Table 3). Mulch had no significant effect on accumulation of total $\mathrm{N}$, while available $\mathrm{N}$ was $8.2 \mathrm{mg} \mathrm{kg}^{-1}$ higher in the $\mathrm{CF}+\mathrm{MU}$ treatment than in the CF treatment. The major influence of treatments on soil $\mathrm{N}$ was probably related to the amount of fertilizer and pig manure applied (Table 2). Nitrogen, as nitrate or ammonium, is highly soluble and moves rapidly in runoff and in soil solutions, and thus available $\mathrm{N}$ increases with mulch. Total $\mathrm{P}$ did not differ between $\mathrm{CF}, \mathrm{CF}+\mathrm{MU}$, and PM treatments, because $\mathrm{P}$ is relatively immobile in soils and does not move far from the application site (Cai et al. 1996). Although the differences were not significant, Table 4 shows high $\mathrm{N}$ and $\mathrm{P}$ concentrations in the mulch treatment. Straw mulch was rich in phosphorous and nitrogen; therefore, the amount of $\mathrm{N}$ and $\mathrm{P}$ in the soil is likely to increase. The high available $\mathrm{P}$ concentration was associated with greater input of organic matter. Levels of available $\mathrm{P}$ increased in the following order $\mathrm{CF}<\mathrm{CF}+\mathrm{MU}<\mathrm{CF}+\mathrm{PM}+\mathrm{MU}<\mathrm{PM}$. Organic amendments can directly affect $P$ availability via three mechanisms: (1) they can adsorb to soil minerals, and compete with P for adsorption sites; (2) they can complex with surface-bound aluminum or iron to form soluble organic-metal compounds substituting for, and releasing, previously adsorbed P; or (3) adsorb to soil particles at nonspecific adsorption sites, increasing the surface negative charge of the particle and resulting in reduced electrostatic attraction of $\mathrm{P}$ to the soil surface (Traina et al. 1986; Ohno et al. 2007). 
Table 4 Soil nutrient conditions along slope under different soil management practices in a contour hedgerow system

\begin{tabular}{|c|c|c|c|c|c|c|}
\hline Treatments & $\begin{array}{l}\text { Slope } \\
\text { position }\end{array}$ & $\begin{array}{l}\text { Organic matter } \\
\left(\mathrm{g} \mathrm{kg}^{-1}\right)\end{array}$ & $\begin{array}{l}\text { Total N } \\
\left(\mathrm{g} \mathrm{kg}^{-1}\right)\end{array}$ & $\begin{array}{l}\text { Total P } \\
\left(\mathrm{g} \mathrm{kg}^{-1}\right)\end{array}$ & $\begin{array}{l}\text { Available N } \\
\left(\mathrm{mg} \mathrm{kg}^{-1}\right)\end{array}$ & $\begin{array}{l}\text { Available P } \\
\left(\mathrm{mg} \mathrm{kg}^{-1}\right)\end{array}$ \\
\hline \multirow[t]{3}{*}{ Control } & Upper & $7.75 \mathrm{c}$ & $0.51 \mathrm{c}$ & $0.49 \mathrm{c}$ & $37.63 \mathrm{c}$ & $2.42 \mathrm{~b}$ \\
\hline & Middle & $9.36 b$ & $0.65 b$ & $0.56 b$ & $42.88 b$ & $3.31 \mathrm{ab}$ \\
\hline & Lower & $11.86 a$ & $0.76 \mathrm{a}$ & $0.60 \mathrm{a}$ & $53.53 \mathrm{a}$ & $4.12 \mathrm{a}$ \\
\hline \multirow[t]{3}{*}{$\mathrm{CF}$} & Upper & $9.56 \mathrm{c}$ & $0.72 \mathrm{c}$ & $0.64 \mathrm{c}$ & $45.72 \mathrm{c}$ & $4.11 \mathrm{c}$ \\
\hline & Middle & $11.92 b$ & $0.86 b$ & $0.78 b$ & $56.10 \mathrm{~b}$ & $4.60 \mathrm{~b}$ \\
\hline & Lower & $13.54 \mathrm{a}$ & $0.98 \mathrm{a}$ & $0.86 a$ & $61.41 \mathrm{a}$ & $5.64 \mathrm{a}$ \\
\hline \multirow[t]{3}{*}{$\mathrm{CF}+\mathrm{MU}$} & Upper & $12.80 \mathrm{~b}$ & $0.86 b$ & $0.79 b$ & $58.91 \mathrm{~b}$ & $6.04 b$ \\
\hline & Middle & $13.05 b$ & $0.90 \mathrm{~b}$ & $0.86 a b$ & $62.68 \mathrm{ab}$ & $6.37 \mathrm{a}$ \\
\hline & Lower & $14.32 \mathrm{a}$ & $1.01 \mathrm{a}$ & $0.91 \mathrm{a}$ & $65.10 \mathrm{a}$ & $6.54 \mathrm{a}$ \\
\hline \multirow[t]{3}{*}{ PM } & Upper & $15.69 b$ & $0.86 b$ & $0.69 \mathrm{c}$ & $49.71 \mathrm{c}$ & $7.78 b$ \\
\hline & Middle & $16.29 \mathrm{~b}$ & $0.95 b$ & $0.84 b$ & $57.92 b$ & $8.67 b$ \\
\hline & Lower & $19.38 \mathrm{a}$ & $1.06 \mathrm{a}$ & $0.99 a$ & $68.58 \mathrm{a}$ & $12.28 \mathrm{a}$ \\
\hline \multirow[t]{3}{*}{$\mathrm{CF}+\mathrm{PM}+\mathrm{MU}$} & Upper & $15.91 \mathrm{a}$ & $1.07 \mathrm{a}$ & $0.85 b$ & $75.82 b$ & $8.72 b$ \\
\hline & Middle & $16.22 \mathrm{a}$ & $1.17 \mathrm{a}$ & $0.93 \mathrm{ab}$ & $78.94 \mathrm{a}$ & $9.35 \mathrm{a}$ \\
\hline & Lower & $17.28 \mathrm{a}$ & $1.15 \mathrm{a}$ & $0.97 \mathrm{a}$ & $80.22 \mathrm{a}$ & $9.71 \mathrm{a}$ \\
\hline
\end{tabular}

MU, PM, and CF are wheat straw mulch, pig manure, and chemical fertilizer, respectively

Means within a column for the same treatment with the same letter $(\mathrm{a}-\mathrm{c})$ are not significantly different at $P=0.05$

Available $\mathrm{K}$ in all treatments was at sufficient levels according to standards for classification and gradation of soil fertility in China (National Soil Survey Office 1992). Even control and CF treatments that had not received $\mathrm{K}$ fertilizer had adequate $\mathrm{K}$ levels, possibly because of the release of nonexchangeable K. Some studies in the Three Gorges Area showed that where $\mathrm{K}$ inputs were inadequate, the $\mathrm{K}$ needs of the crop were largely met from the non-exchangeable $\mathrm{K}$ fractions of the soil (Cai et al. 1996). In addition, available $K$ increased in the treatments in which pig manure and straw mulch were added. Both these organic matters were rich in potassium $\left(>20 \mathrm{~g} \mathrm{~kg}^{-1}\right)$, and the amount of potassium in the soil was likely to increase.

\section{Soil deterioration indices}

As the soil deterioration index reflects the percent changes in soil nutrients from their values in reference soil, it can be regarded as an indication of the degree of soil deterioration (or improvement). Values for SOM, TN, TP, and \% WSA were included in this calculation according to results of our previous study in the Wangjiaqiao watershed and other studies conducted in the Three Gorges Area (Shi et al.
1999; He 2003; Li et al. 2004). The calculated soil deterioration indices are shown in Fig. 2.

Soils in the control had a significantly lower (i.e., negative) deterioration index $(-19.3 \%)$ than the other treatments. In contrast, the deterioration indices for soils under $\mathrm{CF}+\mathrm{MU}, \mathrm{PM}$, and $\mathrm{CF}+\mathrm{PM}+\mathrm{MU}$

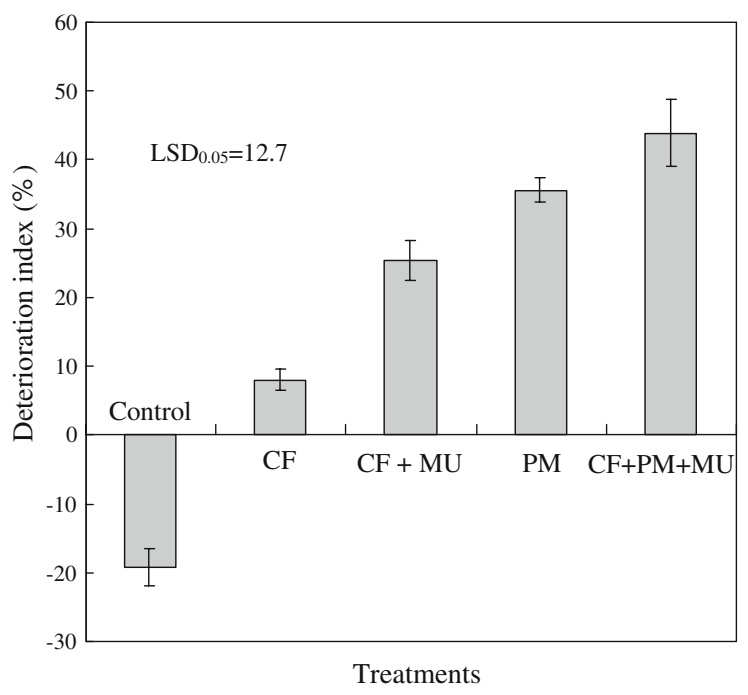

Fig. 2 Soil deterioration index for different treatments in contour hedgerow system (MU, mulch with wheat straw; PM, pig manure; and $\mathrm{CF}$, chemical fertilizer) 
treatments were positive (27.2-43.9\%), which indicated that soil fertility had been significantly improved under these management practices. The deterioration index in the chemical fertilizer treatment was also positive (8.7\%), but was not significantly different compared with the reference soil. These soil deterioration indices clearly showed that soil quality significantly deteriorated when the steeplands were planted in contour hedgerows. The main reason was that there was no input of fertilizer or manure, which resulted in deteriorated soil conditions that were unfavorable for vegetation growth. This resulted in a vicious cycle between soil and vegetation. Therefore, these soil deterioration indices clearly indicated that mulch and fertilizer/manure addition improve soil fertility in contour hedgerow systems.

\section{Soil fertility spatial variation between hedgerows}

Spatial variation in soil nutrients on terraces was found in various treatments, although the pattern and the magnitude of spatial variation were varied among treatments (Table 4). In general, soil fertility in the lower alley became more favorable compared with the upper alley due to the combined effect of water erosion and tillage practices, and due to the movement of fertile topsoil from the upper part of the alley to the lower part (Agus et al. 1999). There were significant differences in all soil properties along the slope in the control and CF treatments (Table 4). At the lower slope position in the control, organic matter increased by $53.0 \%$, total $\mathrm{N}$ by $49.1 \%$, total $\mathrm{P}$ by $22.4 \%$, available $\mathrm{N}$ by $44.3 \%$, and available $\mathrm{P}$ by $70.2 \%$ compared with values in the upper slope position. In the $\mathrm{CF}$ treatment, organic matter, total $\mathrm{N}$, total $\mathrm{P}$, available $\mathrm{N}$, and available $\mathrm{P}$ in the lower slope position were increased by 41.6, 36.1, 34.5, 34.3, and $37.2 \%$, respectively, compared with values in the lower slope position. Although there was a similar trend in soil nutrients along slopes in the control and CF treatments (Table 4), no significant differences were found in soil organic matter, total $\mathrm{N}$, and available $\mathrm{P}$ between middle and upper slope positions under $\mathrm{CF}+\mathrm{MU}$ and $\mathrm{PM}$ treatments. In contrast to the other treatments, the $\mathrm{CF}+\mathrm{PM}+\mathrm{MU}$ treatment resulted in the best distribution of soil nutrients along the slope. Soil organic matter and total $\mathrm{N}$ did not differ significantly among the different slope positions. Total $\mathrm{P}$, available $\mathrm{N}$, and available $\mathrm{P}$ did not differ significantly between middle and lower slope positions (Table 4).

This study shows that addition of mulch and pig manure can alleviate the magnitude of spatial variations in soil fertility. Despite that fact that some differences were not statistically significant, soil nutrients were distinctly higher in the lower part of the alleys between hedgerows under the $\mathrm{CF}+\mathrm{PM}+\mathrm{MU}$ treatment (Table 4). The problem with the current fertilization practice is that the same dose of fertilizer and pig manure was applied over the whole alley, which resulted in insufficient application to the upper part and excess application to the lower part. In addition, the lower part would likely receive a part of the dose applied to the upper part after the next tillage operation, which would also increase spatial variability in soil fertility. Fertility gradients between hedgerows may also mean that alternative cropping practices could be employed within this soil conservation system (Walle and Sims 1999). The more fertile zone could be used for main crops, and the less fertile zone could be used for the production of secondary crops, for supplemental uses such as mulch or fodder, or fallowed to fit the farmers' needs.

Crop and hedge responses to soil fertility

Average crop yields and hedge production during the study year are shown in Fig. 3. Significantly lower

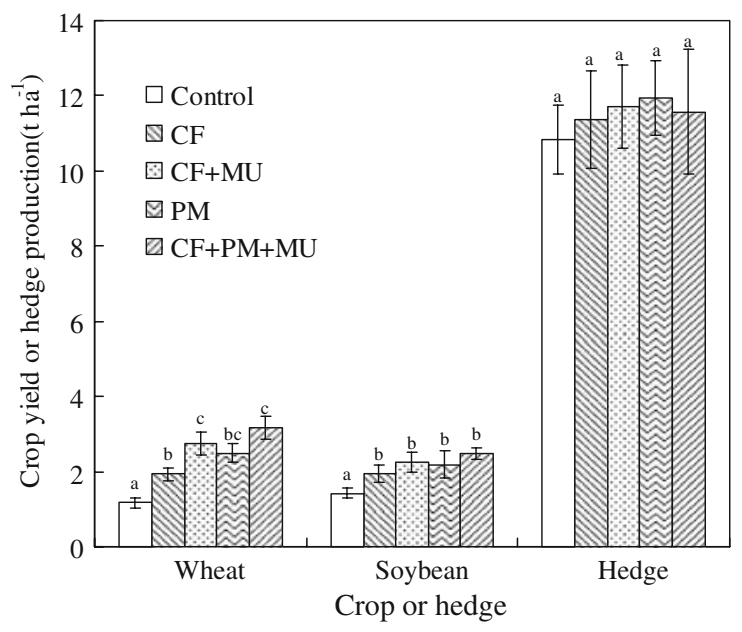

Fig. 3 Average crop yields and hedge production under long term soil management (MU, PM, and CF are wheat straw mulch, pig manure, and chemical fertilizer, respectively. Vertical bars represent standard errors, and bars followed by different letters are significantly different at $P<0.05$ ) 
grain yields of both soybean and wheat were obtained in the control treatment, indicating the benefits of chemical fertilizer, pig manure, and/or mulch on crop performance. The $\mathrm{CF}+\mathrm{MU}$ and $\mathrm{CF}+\mathrm{PM}+\mathrm{MU}$ treatments resulted in significantly higher grain yield of wheat compared with the CF treatment, but the difference in seed yield of soybean was not significant except in the control. Although the mean annual precipitation in the Wangjiaqiao watershed is approximately $1,010 \mathrm{~mm}$, it has clear seasonal and interannual variations. The maximum annual precipitation reaches $1,350 \mathrm{~mm}$, while the minimum was only $784 \mathrm{~mm}$ during the experimental period. Additionally, $70 \%$ of rainfall occurs between May and September. Therefore, water is also a principal factor in determining wheat yield, and mulch can significantly improve wheat yield due to its effects on increasing soil moisture. During the experimental period, hedge growth did not vary significantly among the experimental plots. This is likely because Vetiver grows well even at low soil fertility and under very dry conditions (Greenfield 1989).

\section{Conclusions}

The study showed the importance and benefits of long-term application of chemical fertilizer and pig manure alone or in conjunction with mulch. Chemical fertilizer clearly improves nutrient status in topsoil, while pig manure also increases the amount of soil organic matter. This increase in organic matter was associated with improved stability of soil aggregates, reduced bulk density, and reduced penetration resistance of the soil. Our results indicate that chemical fertilizer in combination with pig manure and mulch should form part of soil management practices in this intensively cultivated steepland region. Such management practices will result in better soil fertility and higher crop productivity. Further, mulch or pig manure can alleviate the magnitude of spatial variation, but cannot offset soil fertility gradients because tillage results in significant soil movement. More favorable soil properties were found at lower positions of hedgerow alleys, regardless of the different management practices.

Acknowledgments Financial support for this project was provided by the National Basic Research Program of China
(Project No. 2007CB407201) and the National Natural Science Foundation of China (No. 90502007). The authors thank the staff of the Soil and Water Conservation Experimental Station of Zigui County for assistance with field management.

\section{References}

Adejuwon JO, Ekanade O (1988) A comparison of soil properties under different land use types in a part of the Nigerian cocoa belt. Catena 15:319-331. doi:10.1016/ 0341-8162(88)90054-9

Agus F, Garrity DP, Cassel DK (1999) Soil fertility in contour hedgerow systems on sloping oxisols in Mindanao, Philippines. Soil Tillage Res 50:159-167. doi:10.1016/ S0167-1987(99)00005-7

Albiach R, Canet R, Pomares F, Ingelmo F (2001) Organic matter components and aggregate stability after application of different amendments to a horticultural soil. Bioresour Technol 76:125-129. doi:10.1016/S0960-8524 (00)00090-0

Benbi DK, Biswas CR, Bawa SS, Kumar K (1998) Influence of farmyard manure, inorganic fertilizers and weed control practices on some soil physical properties in a long-term experiment. Soil Use Manage 14:52-54. doi:10.1111/ j.1475-2743.1998.tb00610.x

Cai CF, Ding SW, Zhang GY, Huang L (1996) A preliminary study on the conditions and losses of nutrients on purple soils in the Three Gorges Area. Geogr Res 15:77-84 in Chinese

Dercon G, Deckers J, Govers G, Poesen J, Sánchez H, Vanegas R, Ramírez M, Loaiza G (2003) Spatial variability in soil properties on slow-forming terraces in the Andes region of Ecuador. Soil Tillage Res 72:31-41. doi:10.1016/S01671987(03)00049-7

Drees LR, Wilding LP, Owens PR, Wu B, Perottoa H, Sierra H (2003) Steepland resources: characteristics, stability and micromorphology. Catena 54:619-636. doi:10.1016/S03418162(03)00138-3

Du RH, Shi DM, Yuan J (1994) The impact of soil and water losses upon ecosystem and environment in the Three Gorges Area of the Changjiang River. Since Press, Beijing, China (in Chinese)

Greenfield JC (1989) Vetiver grass (Vetiveria spp.): the ideal plant for vegetative soil and moisture conservation. Asia Technical Department, Agriculture Division, The World Bank, Washington, DC

Haynes RJ, Naidu R (1998) Influence of lime, fertilizer, and manure applications on soil organic matter content and soil physical conditions: a review. Nutr Cycl Agroecosyst 51:123-137. doi:10.1023/A:1009738307837

He YR (2003) Purple soils in China. Science Press, Beijing, China (in Chinese)

Hurlbert SH (1984) Pseudoreplication and the design of ecological field experiments. Ecol Monogr 54(2):187-211. doi: $10.2307 / 1942661$

Isaac L, Wood CW, Shannon DA (2003) Pruning management effects on soil carbon and nitrogen in contour-hedgerow cropping with Leucaena leucocephala (Lam.) De Wit on sloping land in Haiti. Nutr Cycl Agroecosyst 65:253-263. doi:10.1023/A:1022600720226 
ISSAS (1978) Soil physical and chemical analysis. Shanghai Science and Technology Press, Shanghai, China (in Chinese)

Lal R (1989a) Agroforestry systems and soil surface management of a tropical alfisol: II water runoff, soil erosion, and nutrient loss. Agrofor Syst 8:239-242. doi:10.1007/ BF00129651

Lal R (1989b) Conservation tillage for sustainable agriculture: tropics vs. temperate environments. Adv Agron 42:85197. doi:10.1016/S0065-2113(08)60524-6

Layton JB, Skidmore EL, Thompson CA (1993) Winter-associated changes in dry-soil aggregation as influenced by management. Soil Sci Soc Am J 57:1568-1572

Li QL, Huang Y, Zeng XY (2004) Soil fertility of cultivated land in the Three Gorges Area. Chinese J Soil Sci 35:257260 (in Chinese)

Liu GS (1996) Soil physical and chemical analysis and description of soil profiles. Chinese Standards Press, Beijing, China (in Chinese)

National Soil Survey Office (1992) Soil survey technique in China. Agricultural Press, Beijing, China (in Chinese)

Ohno T, Hoskins BR, Erich MS (2007) Soil organic matter effects on plant available and water soluble phosphorus. Biol Fertil Soils 43:683-690. doi:10.1007/s00374-0060150-1

Schjonning P, Christensen BT, Carstensen B (1994) Physical and chemical properties of a sandy loam receiving animal manure, mineral fertilizer or no fertilizer for 90 years. Eur J Soil Sci 45:257-268. doi:10.1111/j.1365-2389.1994. tb00508.x

Sharma KL, Mandal UK, Srinivas K, Vittal KPR, Mandal B, Grace JK, Ramesh V (2005) Long-term soil management effects on crop yields and soil quality in a dryland Alfisol. Soil Tillage Res 83:246-259. doi:10.1016/j.still.2004. 08.002
Shaw BT, Haise HR, Farnsworth RB (1942) Four years experience with a soil penetrometer. Soil Sci Soc Am Proc $7: 48-55$

Shen YC (1998) Study on soil and water conservation benefit to agricultural technology of hedgerow in the Three Gorges Area. J Soil Water Conserv 4:61-66 (in Chinese)

Shi ZH, Cai CF, Zhang GY (1999) Comprehensive evaluation soil fertility at the small watershed level in Three Gorges Area: a case study in Wangjiaqiao watershed. Chinese J Soil Water Conserv 14:74-81 (in Chinese)

Sun H, Tang Y, Xie J (2008) Contour hedgerow intercropping in the mountains of China: a review. Agrofor Syst 73:6576. doi:10.1007/s10457-008-9113-x

Tisdall JM, Oades JM (1982) Organic matter and water-stable aggregates in soils. J Soil Sci 33:141-163. doi:10.1111/ j.1365-2389.1982.tb01755.x

Traina SJ, Sposito G, Hesterberg D, Kafkafi U (1986) Effects of $\mathrm{pH}$ and organic acids on orthophosphate solubility in an acidic, montmorillonitic soil. Soil Sci Soc Am J 50:45-53

Walle R, Sims B (1999) Fertility gradients in naturally formed terraces on Honduran hillside farms. Agron J 91:350-353

Xu F, Cai QG, Wu SA, Zhang GY (2000) A study on soil nutrient loss by slope eco-engineering in the Three Gorges Area: taking the contour hedgerows as an example. Geogr Res 19:303-310 (in Chinese)

Zhao AJ, Xu KC, Peng YX (2004) Preliminary report on soil and water loss prevention tests by planting living hedges on slope lands in the Three Gorges Area. Soil Water Conserv China 11:23-25 (in Chinese)

Zhou WC (2001) Impact of land slope and sea level elevation on the economic development in the Three Gorges Area. Resour Environ Yangtze Basin 10:15-21 (in Chinese) 